\title{
Jurassic Geology after the Second World War: From the Luxembourg Symposia $(1962,1967)$ to the William Smith Bicentenary Symposium (London, 1969)
}

\author{
Nicol MORTON ${ }^{1}$ \\ with contributions by John COPE ${ }^{2}$, Hugh TORRENS ${ }^{3}$ and John WRIGHT ${ }^{4}$
}

\section{THE LUXEMBOURG JURASSIC SYMPOSIA 1962 AND 1967}

The Second World War (1939-1945) was a major catastrophe for millions of people. This applied also to geologists who had previously been involved in international collaboration and scientific exchanges. For specialists in Jurassic geology the first post-war event of international importance was the $19621^{\text {st }}$ Luxembourg Jurassic Symposium, organised by Pierre L. Maubeuge. This resulted in a lot of agreement and progress in rationalising international stratigraphical nomenclature at Stage level was achieved.

Five years later the $2^{\text {nd }}$ Luxembourg Jurassic Symposium, also organised by Pierre Maubeuge, was held in 1967. International recognition of the importance of distinguishing lithostratigraphy and chronostratigraphy with precise definitions was becoming established and featured in presentations. Progress included agreement to accept an Aalenian Stage (previously part of the Bajocian for some) as the base of the Middle Jurassic, the Callovian in the Middle Jurassic, and a longer Kimmeridgian Stage. Basal boundary stratotypes for Stages were discussed for the first time. A precise stratotype for the Bathonian Stage proposed by Hugh S. Torrens could have been the first international GSSP proposal, but publication of the proceedings was delayed until 1974. Eventually, we had to wait until a nearly identical proposal was accepted in 2007.

Subsequently two Symposia were organised in 1969 - the first in April in Great Britain and the second in September in Hungary.

\section{WILLIAM SMITH BICENTENARY THE INTERNATIONAL FIELD SYMPOSIUM ON THE BRITISH JURASSIC 1969}

Both of the Luxembourg Symposia included field excursions and long programmes of oral presentations on a wide range of topics. To celebrate the bicentenary of William Smith's birth, the British Jurassic Committee decided to concentrate on demonstrating the British Jurassic, especially in the field. As presented in the first circular (provided by Andrzej Wierzbowski who could still find his!):

\footnotetext{
${ }^{1}$ Le Chardon, 180 Chemin Brugière, F-07200 Vogüé, France; nicol.morton@orange.fr.

${ }^{2}$ Department of Natural Sciences, National Museum Wales, Cathays Park, Cardiff CF10 3NP, U.K.; John.Cope@honorary.museumwales.ac.uk.

${ }^{3}$ Department of Geography, Geology and the Environment, Keele University, Keele, Staffordshire, ST5 5BG, U.K.; h.s.torrens@keele.ac.uk.

${ }^{4}$ Department of Geology, Royal Holloway, University of London, Egham, Surrey, TW20 0EX, U.K.; john_wright953@ntlworld.com.
} 
"The object of the symposium is to provide other European Jurassic specialists, especially younger workers, with an opportunity of seeing some of the classic British sections, of examining type collections and of informal discussions with each other and their British colleagues".

A "post-mortem" report on the Symposium was published on $28^{\text {th }}$ November 1969 by Derek V. Ager in Proceedings of the Geological Society of London no. 1658, p. 215-217.

The organising committee was:

- President: Peter C. Sylvester-Bradley;

- Vice-Presidents: Desmond T. Donovan, Michael R. House, Peter E. Kent and Vernon Wilson;

- General Secretary: Derek V. Ager, assistant Mary E. Pugh;

- Assistant Secretary (membership): Nicol Morton;

- Treasurer: John H. Callomon;

- Editor and Printer of Excursion Guides: Hugh S. Torrens;

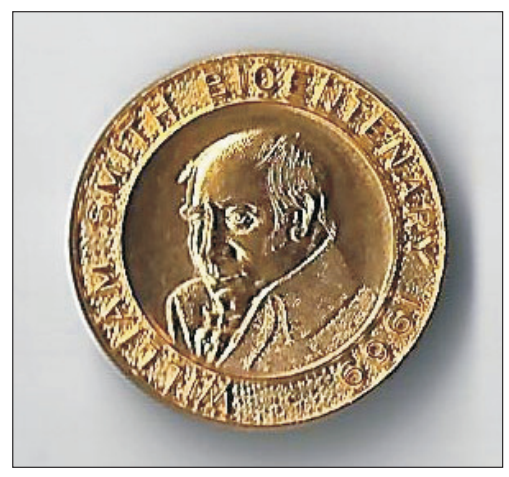

Fig. 1. William Smith Bicentenary medal, courtesy John Cope

- Programme for accompanying members: Peigi Wallace;

- Other Members: Raymond Casey, John C.W. Cope, William T. Dean, Michael K. Howarth, Noel G. Morris.

In the first part, centred in London at Imperial College, oral presentations and discussion sessions summarised the main geological features of the British Jurassic and presenting new ideas sometimes tentative and not yet ready for publication and with three one-day field excursions to areas within reach of London.

In the second part a choice was offered between four one-week field excursions to important areas of outcrops of Jurassic rocks.

Generous financial sponsorship was raised from the IUGS, the British Council and The Royal Society, so that invitations to participate could be sent to active researchers, known to the organising committee, in Eastern European countries who would not otherwise be able to participate for financial reasons. All fees in the UK would be paid and only travel to/from London had to be raised by the invitee. Members of the organising committee selected invitees based on personal knowledge. For each one an invitation letter was sent to the person and a separate letter to the director of the institution requesting agreement and support.

I hope my records and memory are correct:

- Bulgaria: V.L. Shopov, P.V. Tchoumatchenko;

- Czechoslovakia: M. Eliáś, E. Hanzliková, V. Houša, O. Nekvasilová, M. Siblik;

- Hungary: A. Galácz, B. Géczy, A. Vörös;

- Poland: R. Dadlez, K. Dayczak-Calikowska, S.M. Gąsiorowski, J. Kopik, J. Kutek, H. Makowski, L. Malinowska;

- Romania: A. Badaluta-Nastaseanu, M. Iordan, S. Nastaseanu, D.C. Patrulius.

- Yugoslavia: M. Anđelkovic.

In addition A. Wierzbowski (Poland) was at the time being hosted in the UK by the British Council, who funded his participation in both parts of the programme.

It was recognised that this approach could not be applied for Russian colleagues, but partially successful suggestions were made to the Russian authorities to send younger active researchers rather than senior academicians. More than 20 delegates participated. A minor problem was that their "translator" came with only high-heeled shoes, partly resolved by Sheila Morton taking her shopping to buy "wellington boots".

In total there were 117 overseas visitors from 24 countries and about 60 British specialists participating in various ways in lectures, discussions and excursions.

\section{PROGRAMME, PART 1, LONDON: ALL PARTICIPANTS}

$$
9^{\text {th }} \text { April: }
$$

Assemble in London:

The meeting of the International Symposium on the British Jurassic started with a reception given by Shell at the Shell Centre on the South Bank, London. Joan Mary Eyles opened this with an introductory lecture on William Smith (a summary is published in the Guide to Field Excursions from London). The 23 ${ }^{\text {rd }}$ William Smith Lecture of the Geological Society of 
London was given by Rudolf Trümpy, Stratigraphy in Mountain Belts (published December 1970 in Quarterly Journal of the Geological Society, 126: 293-318).

Before the reception, a visit was arranged to the top floor of the Shell Centre with a spectacular view of central London. By chance Big Ben on the Houses of Parliament sounded the hour for all to hear. One lady from eastern Europe turned to us with tears in her eyes to say that she had never expected to be here in person to hear this sound - their symbol of hope for the future during the war!

$$
10^{\text {th }}-12^{\text {th }} \text { April }
$$

In the Geology Department of Imperial College a series of lectures on the British Jurassic, with ample time for informal discussions and examination of exhibits, including in the neighbouring British Museum (Natural History) and the Geological Museum of the Geological Survey. Invited lecturers summarised the main geological features of the British Jurassic and presenting new, sometimes tentative, ideas not yet ready for publication. Another more international session, with invited lectures by D. Patrulius (Romania), C. Sturani (Italy) and R.W. Imlay (USA), and comments by C. Leanza (Argentina) and G.E.G. Westermann (Canada), explored faunal provinces, again not for publication.

An "opening dinner" was held in Imperial College on the $10^{\text {th }}$ April. My menu card (Fig. 2) shows details of the event and a lot of souvenir autographs!

There was also a "sherry reception" at the Institute of Geological Sciences (Geological Survey) hosted by Kingsley C. Dunham.
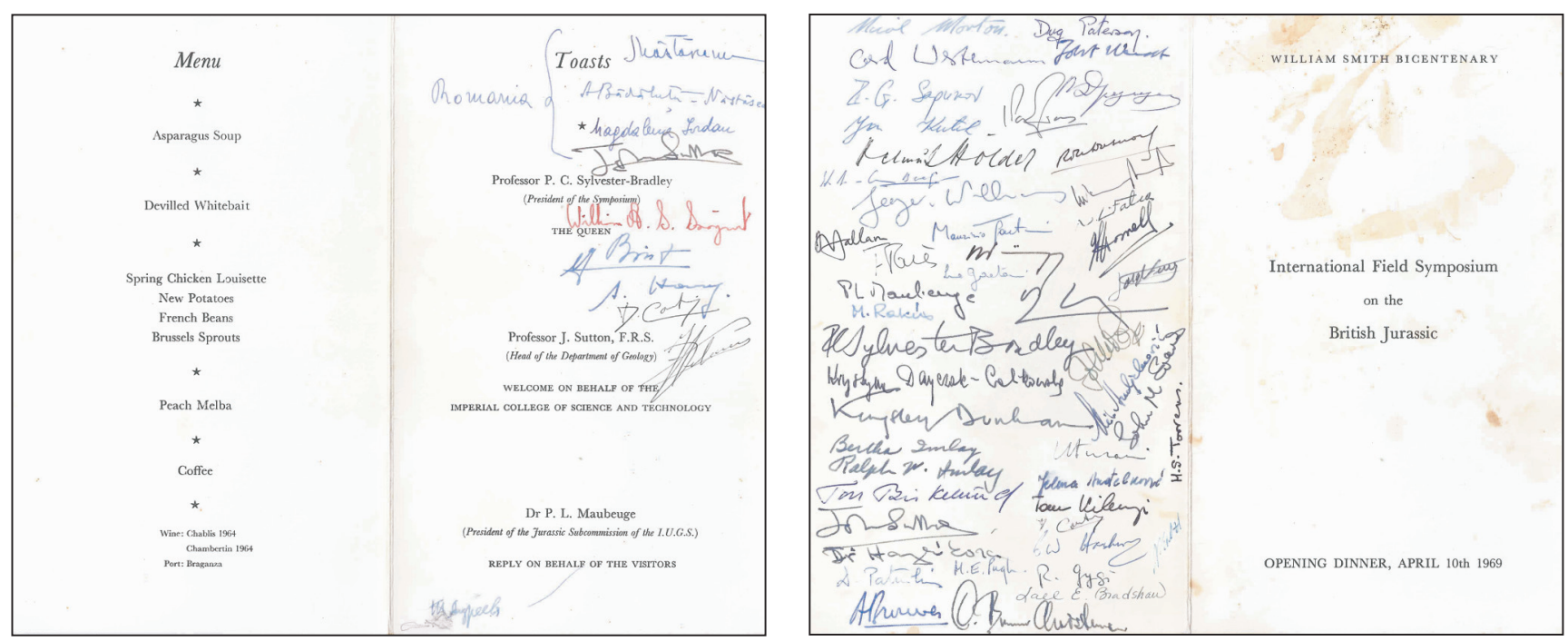

Fig. 2. The menu and programme for the opening dinner in Imperial College, London, on $10^{\text {th }}$ April 1969 with the autographs of some of the participants. How many can you identify?

$$
13^{\text {th }}-15^{\text {th }} \text { April }
$$

One-day field excursions from London:

For each of the excursions a guide book was prepared, edited and published by Hugh S. Torrens, at the Geology Department, Keele University. About 180 sets were printed and distributed to participants and a further 120 sets sold via the Geologists' Association and the Geological Society, so the guides are properly published and frequently quoted. 


\section{$13^{\text {th }}$ April}

Excursion to the Lias, Inferior Oolite and Great Oolite Series (Bajocian and Bathonian) of the Cotswolds and the Corallian (Oxfordian) of Oxfordshire.

Directors: J.H. Callomon, A. Horton, H.S. Torrens

Including a visit to Highworth, W.J. Arkell's birthplace (1904) and lunch at the Saracen's Head, a public house of Arkell's Swindon Brewery where we were welcomed by Sir Noel Arkell (brother of W.J. Arkell) with gifts of souvenir beer mats (Fig. 3), a visit to the Wm. Smith Monument (Churchill) and dinner in Whately Hall (Banbury).

$$
14^{\text {th }} \text { April }
$$

Visit to the University of Oxford.

Director: W.S. McKerrow

Including buffet lunch in the Department of Geology, guided tours of Oxford and exhibits in the Museum, a lecture on the history of geology in Oxford and its museum, and "formal" college dinner in the evening at University College, Oxford.

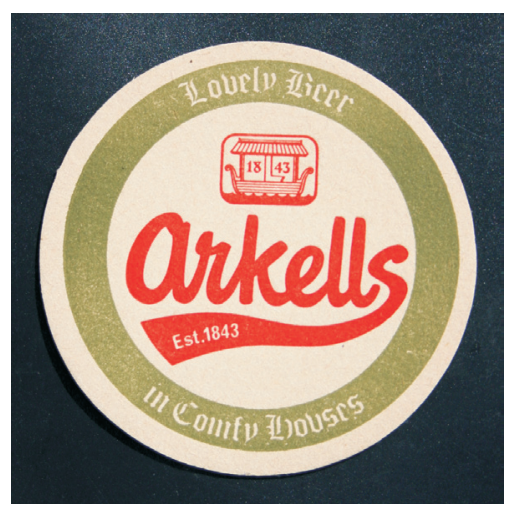

Fig. 3. Souvenir beer mat from the Arkell Brewery, courtesy Andrzej Wierzbowski

$$
15^{\text {th }} \text { April }
$$

Excursion to the Great Oolite Limestone of South Northamptonshire and the Oxford Clay of Buckinghamshire

Directors: J.H. Callomon, A. Horton, H.S. Torrens

Including reception (Fig. 4), lunch and guided tour of the works by the London Brick Company, visit to Woodham pit (Fig. 5) and dinner.

$$
16^{\text {th }} \text { April }
$$

Was left free for informal discussions and longer visits to collections, but a large number opted for a visit to the University of Cambridge. Participants in the excursion to Western Scotland started their journey by overnight train from London.

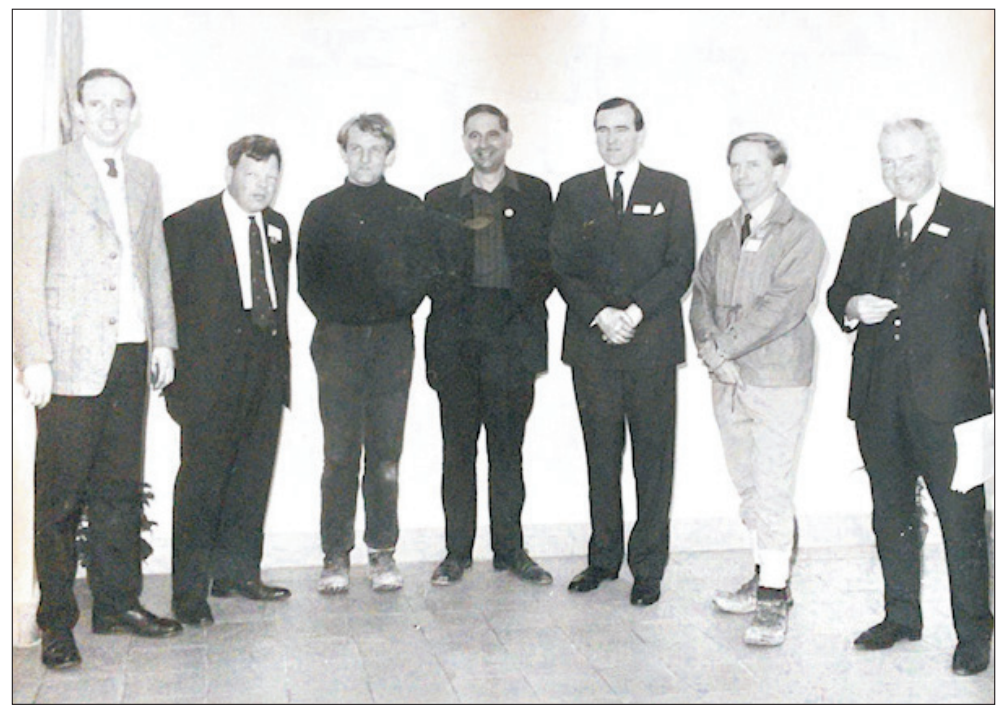

Fig. 4. Welcome reception by the then Directors of the London Brick Company. From left to right - Albert Horton, LBC Director, Hugh Torrens, John Callomon, LBC Director, Derek Ager, LBC Director

\section{PROGRAMME PART 2, MAIN FIELD EXCURSIONS, PARTICIPANTS TO SELECT PREFERENCE}

$$
17^{\text {th }} \text { to } 23^{\text {rd }} \text { April }
$$

Departures from London $17^{\text {th }}$ April (except no. 4 on $16^{\text {th }}$ April by overnight train to Inverness) and return to London on $24^{\text {th }}$ April. For each of the excursions (including from London) a guide book to the Jurassic geology was prepared by the Directors and edited and printed by Hugh Torrens (mainly) in the Geology Department at Keele University. 


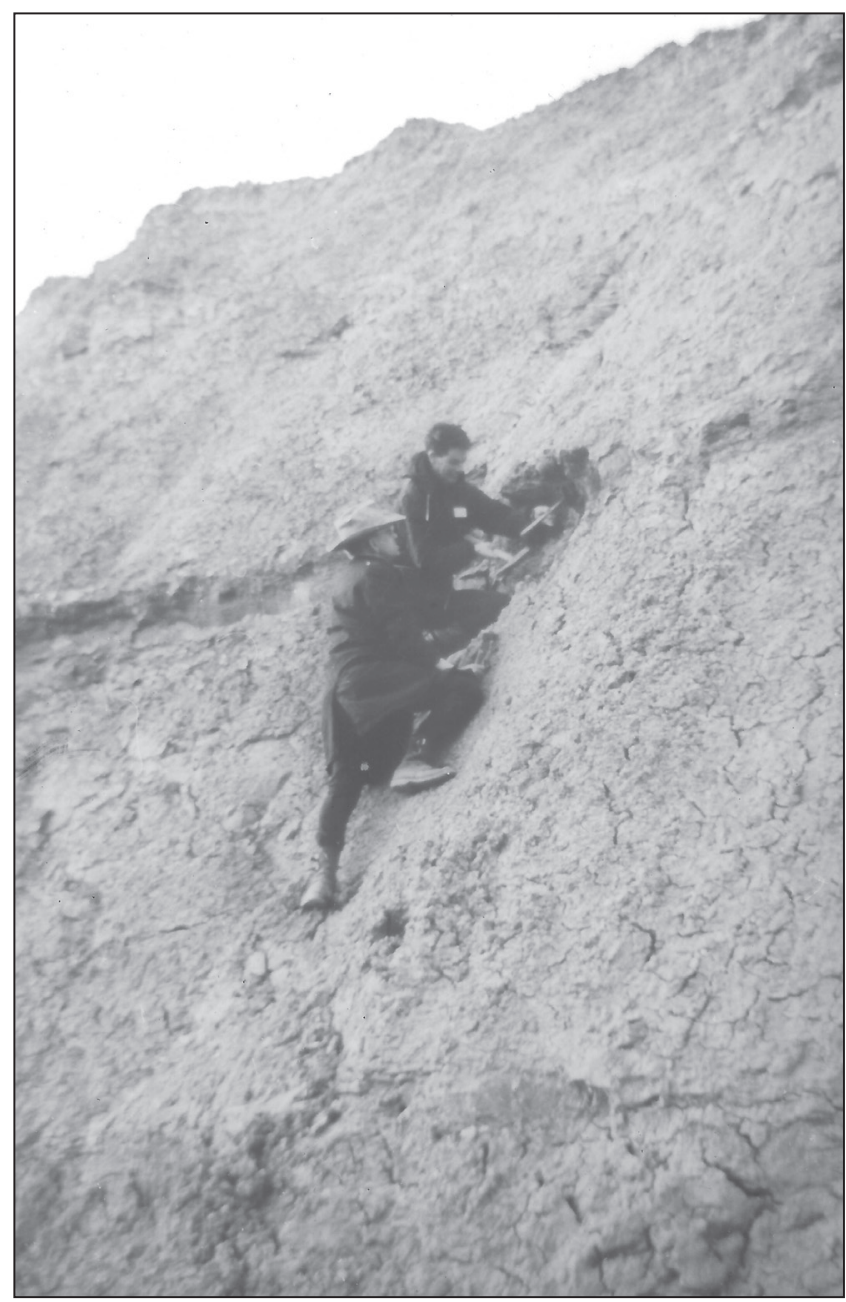

Fig. 5. Pierre Maubeuge, assisted by Nicol Morton extracting a specimen from the Oxford Clay at Woodham Brick Pit, $15^{\text {th }}$ April 1969. Photo by A. Galacz

\section{Dorset and South Somerset, by John C.W. Cope}

\author{
Directors: John C.W. Cope (Leader), J. H. Callomon,
} R.G. Clements, A. Hallam, C.F. Parsons, H. Prudden, H.S. Torrens, I.M. West

As expected, this was the most popular of the field-trips and included delegates from most western European countries and elsewhere, as well as a wide range of participants from behind the 'Iron Curtain' including Russia, Bulgaria, Czechoslovakia, Hungary, Poland, Romania and Yugoslavia.

John Cope writes: "The group was accommodated at the Fairhaven Hotel on Weymouth sea-front where the group photograph (Fig. 6) was taken. This was an hotel that I had used regularly for student parties and I knew that the food was of good standard and that portions were generous; it was also fully licensed. The hotel manager was a most affable character who also happened to be a town councillor.

There were problems with the accommodation, however, and some room juggling was needed on arrival. In the context at that time of recent events, the Czechoslovak group refused to be on the same floor as the USSR delegates! The Scandinavian delegates were unhappy that the accommodation did not have en suite bathrooms and furthermore that the bathrooms themselves had baths rather than showers. In late 1960s Britain such luxuries would have put accommodation out of reach of the group! "

[Hugh S. Torrens adds: Near the Fairhaven, they were then filming John Schlesinger's fine Hardy film, Far from the Madding Crowd (released later in 1969) and so there were a lot of Rolls Royces etc to be seen there. One of the Russians asked me why, and I replied "Even the proletariat can afford them here"!]

I had taken a student party to the area two weeks previously so I was up-to-date on the state of the coastal exposures. The fieldwork started at the base of the Jurassic, west of Lyme Regis and worked systematically up the succession to finish the fieldwork with the Purbeck Group at Swanage. The USSR group had their "Intourist interpreter", so we were asked by the Russians to start the day with a muddy or rocky beach so that to save her high-heeled shoes she would make an early return to the coach.

We had fine weather throughout the week, the tides were near-perfect and we were able to show all we wanted (Fig. 7). I do recall though, that on my visit two weeks earlier I had found a large block of the Marlstone Rock Bed, replete with many Pleuroceras. I hid this under other boulders on the beach, but was dismayed on my return to find that it had been discovered and all the ammonites removed. However, numerous Aalenian ammonites were collected from the Inferior Oolite section at Horn Park, near Beaminster, which had recently been enlarged.

To get to see the Kimmeridge Clay in Brandy Bay, Kimmeridge, which is in the Ministry of Defence ranges I had previously had to see the Commanding Officer at Lulworth Camp to seek permission for the party to enter the area. I was supplied with a pile of forms which everyone had to sign saying that "they agreed with the MoD that neither they, nor any dependants, would sue the MoD for any injury or death resulting from their visit". I remember the form ended with a declaration in capitals (I think I can still remember it verbatim) I UNDERSTAND THAT I MAY BE INJURED MAIMED OR KILLED. I WILLINGLY ACCEPT THE RISKS INVOLVED - then a space for the signature. The beaches were littered with various types of ammunition some of which of course may have been live - hence the MoD forms. Fortunately, no espionage, as far 


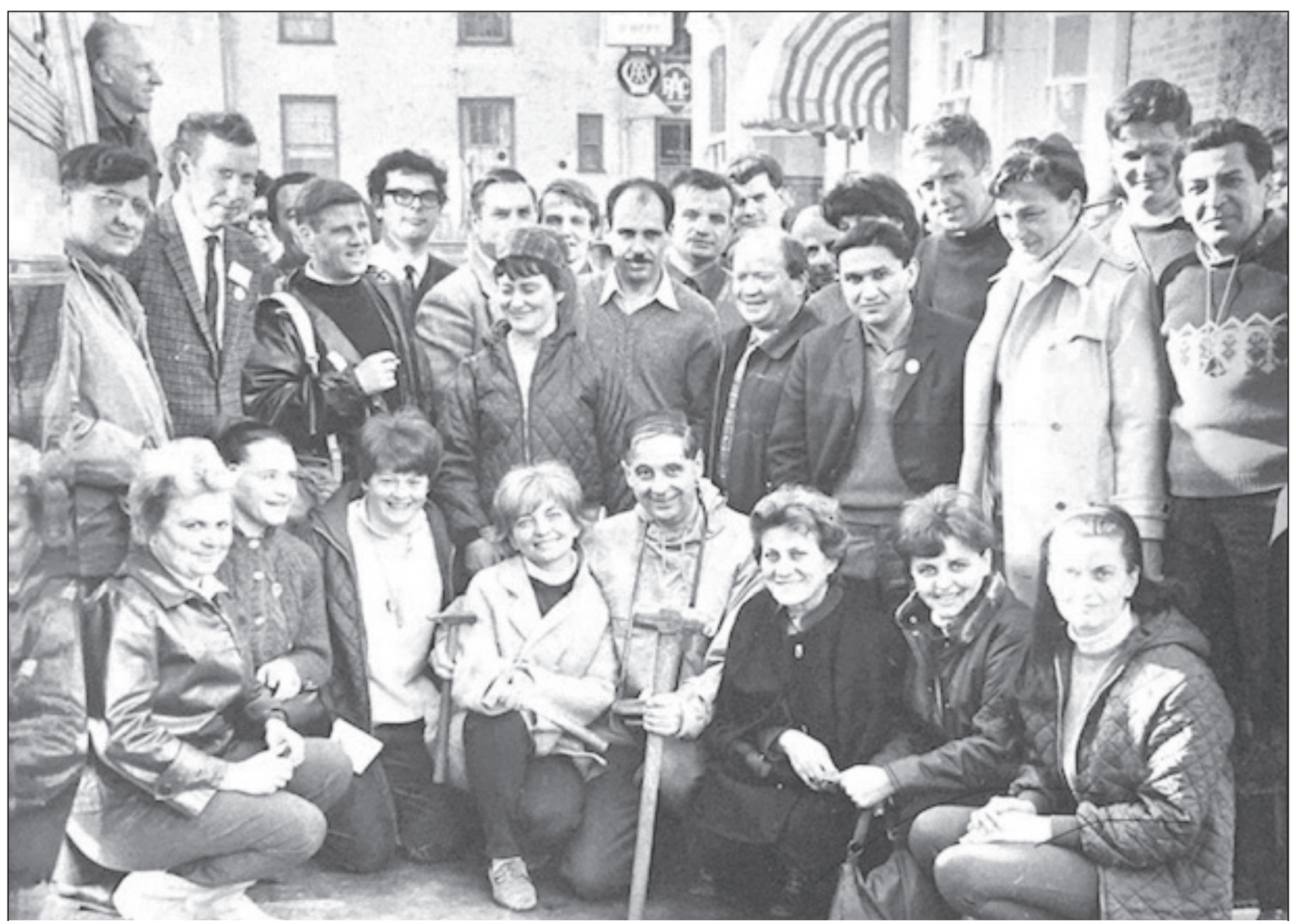

Fig. 6. The Dorset excursion group on the promenade outside the Fairhaven Hotel in Weymouth from Hugh Torrens who can recognize. From right to left - Michael House, John Cope, Colin Parsons, Hugh Torrens (right at back), Raymond Enay, Arnold Zeiss and at right Dan Patrulius; John Callomon in middle of front row

as we know, and no casualties occurred! Of course, now the beaches have been cleared and there is public access whenever the ranges are not firing, which includes most weekends and the whole of August.

For our final night our hotel manager had, through his local council connections, organised an official town reception at the Weymouth mayoral suite and a photo appeared in the local paper. We were entertained most liberally. We were unable to eat much of the food as we'd recently finished an hotel dinner, but the drinks flowed extremely freely for several hours. Everyone had enjoyed the whole trip!

\section{North Somerset and Gloucestershire ${ }^{1}$}

(A) North Somerset, $17^{\text {th }}-21^{\text {st }}$ April

Directors: D.T. Donovan (Leader), H.C. Ivimey-Cook, T.A. Getty

On the morning of $17^{\text {th }}$ April the party left London and travelled by train to Watchet, then by coach to St. Audrie's Bay. The beach section through Upper Triassic through Rhaetic and basal Jurassic Pre-Planorbis Beds and past the headland Het-

${ }^{1}$ Reconstructed from Guide Book by N. Morton with help from J.C.W. Cope and H.S. Torrens. 


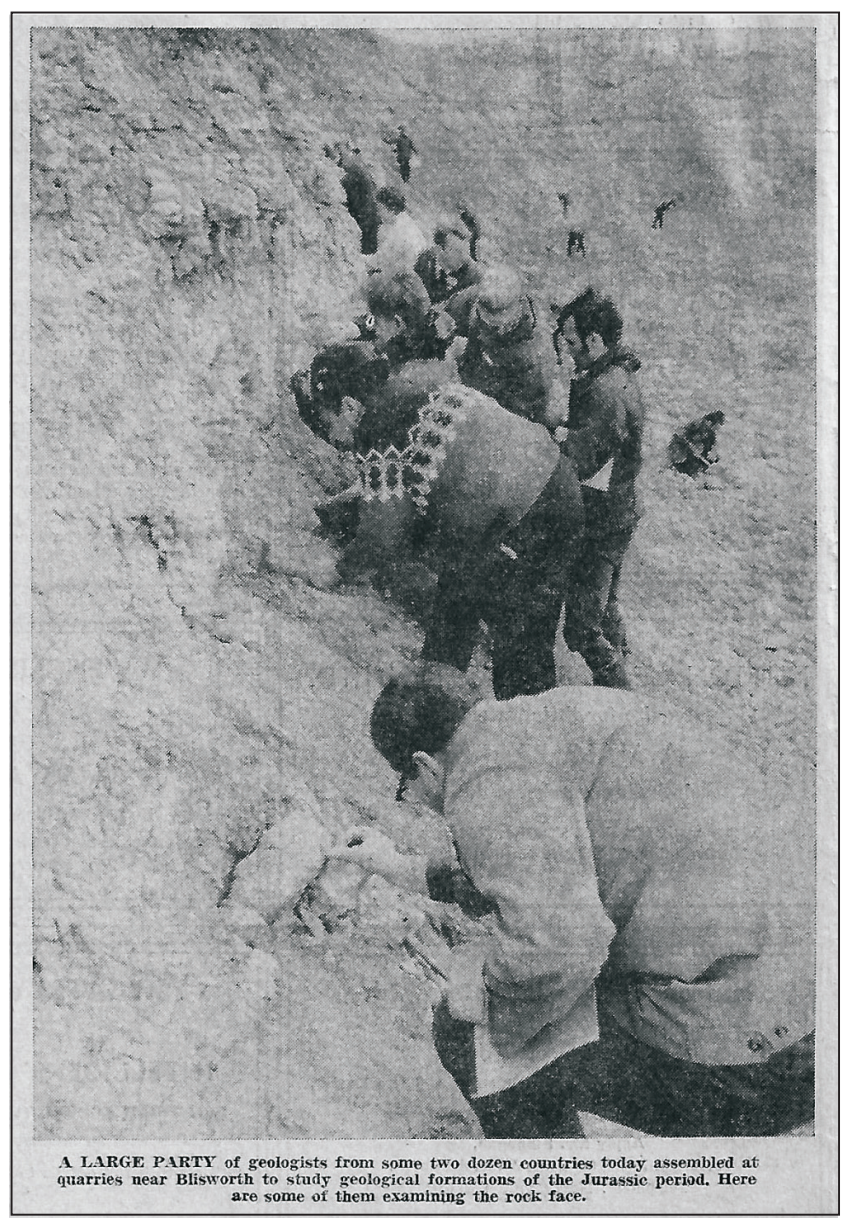

Fig. 7. Some of Dorset excursion group at Blisworth Quarry. Dan Patrulius second, John Cope behind; others? Scan from Northampton Chronicle and Echo (1969) tangian with all ammonite zones, but noting minor faulting and folding. Transport was rejoined at Doniford and overnight near Watchet.

The second field day, $18^{\text {th }}$ April, was devoted first to the Lower Lias (Hettangian and Sinemurian) in offshore facies on the southern shore of the Severn Estuary between Lilstock and Blue Ben. This was followed by a visit to the Upper Lias (Toarcian) at Brent Knoll where unpublished (at the time) details of the stratigraphy were explained on the bus by Alf Whittaker based on-going work by the British Geological Survey. From there the western end of the Mendip Hills was crossed to arrive in Bristol. Overnight at Bristol.

On the $19^{\text {th }}$ April, the only day Wales was visited by an excursion, the party travelled from Bristol to Aust cliff to view the estuary of the River Severn and the famous section through the Triassic/Jurassic boundary (to be visited at another locality later). We then crossed the Severn Bridge to the northern shore of the Severn Estuary. At Ogmore-by-Sea the complex relationships between Carboniferous Limestone and Jurassic were demonstrated: Lower Lias in the coastal/nearshore facies, such as the Sutton Stone and the overlying Southerndown Beds were seen to pass rapidly laterally and vertically into "normal" Hettangian Blue Lias facies, which was also seen later in the day some $30 \mathrm{~km}$ to the east at Lavernock where there are no littoral facies and where the base of the Blue Lias rests on Rhaetian Penarth Group, apparently without a break. Return to Bristol.

Sunday $20^{\text {th }}$ April was devoted to exploration south of Bristol to see nearshore condensed Jurassic facies in the Mendip Hills where Carboniferous Limestone (and older strata in the core of the anticlines) is truncated by a nearly level extensively bored erosion surface overlain by remnants of Lower and Middle Jurassic. Fissures in the Carboniferous Limestone with both Triassic and Jurassic fill proves multiple tectonic phases. Along the southern margin of the Mendips quarries showing nearshore facies of Lower Lias (Downside Stone) and Inferior Oolite (Doulting Stone) were visited. Continuing via Frome the Radstock Grove (Kilmersden Road) Quarry demonstrated a classical condensed and discontinuous section of ?Rhaetian, ?Hettangian, Sinemurian and Lower Pliensbachian strata, just over $1 \mathrm{~m}$ total thickness. Return to Bristol.

Monday $21^{\text {st }}$ April was devoted mainly to the Bathonian south and east of Bath. At Combe Hay the argillaceous facies of the Fuller's Earth includes a bentonite layer, of volcanic origin. Slipped blocks of the overlying limestones here covered the remains of a Romano-British building. The depositional environment of the varied carbonate facies and lithostratigraphical units of the Bathonian Great Oolite were demonstrated by visits in several quarries, including Severcombe Farm, Combe Down and Winsley just east of Bath, and at Corsham to the north-east of Bath. Return to Bristol.

The area also has historical sites associated with William Smith to be visited:

1. Rugbourne Manor (now Farm) occupied by William Smith (1792-1795) while employed on the Somerset Coal Canal, leading to his geological observations on the succession of strata;

2. The house of Rev. Joseph Townsend at no. 29 Great Pulteney Street, Bath, where in the presence of the three friends (Smith, Richardson and Townsend), William Smith dictated his observations of the different strata in order of succession in numbered descending order from the chalk down to the coal; this information was written down by Benjamin Richardson. To this was added the names of the most remarkable fossils found, principally supplied by Richardson. The resulting 
manuscript, "Table of the Order of Strata and their embedded Organic Remains in the vicinity of Bath, examined and proved prior to 1799" is preserved by the Geological Society of London.

(B) Cotswolds and Vale of Gloucester, $22^{\text {nd }}-23^{\text {rd }}$ April

\section{Directors: D.V. Ager (Leader), C.F. Palmer}

Tuesday $22^{\text {nd }}$ April The party, with new leaders, left Bristol and travelled north to Wotton-under-Edge (the "Edge" refers to the Inferior Oolite escarpment (a prominent topographic feature of the Cotswolds), visiting sections in the Cotswold Sands (Toarcian) to the top of the Inferior Oolite (Upper Bajocian). Further north visits to The Quarry for Marlstone RockBed (Upper Pliensbachian), Coaley Wood for a section through the Cotswold Sands, Cephalopod Bed (Upper Toarcian to lower Aalenian) into the base of the Inferior Oolite and Leigh's Quarry near Stroud the Inferior Oolite section included the Lower and Upper Freestone (Aalenian), Upper Trigonia Grit (Upper Bajocian) and Clypeus Grit (Upper Bajocian to Lower Bathonian), separated by major non-sequences. Finally at Stonehouse to the west a section through the Upper Pliensbachian was visited, showing a major regional erosion surface at the base of the Spinatum Zone Marlstone Rock bed. Return to Bristol.

Wednesday $23^{\text {rd }}$ April From Bristol again to the north to the Hock Cliff section on the left bank of the River Severn some $10 \mathrm{~km} \mathrm{SW}$ of Gloucester where the Lower Lias (Sinemurian) is famous for fossils, continuing north to Tuffley south of Gloucester for a section through the Middle (Pliensbachian) and Upper Lias into the base of the Inferior Oolite. Travel through Gloucester, the Cathedral is a spectacular Gothic building where the "Domesday Book" was made in 1086. Finally, we continued north-east to just south of Cheltenham where three classic sections of the Inferior Oolite in the Cotswold escarpment were visited, at Birdlip, Crickley Hill and Leckhampton Hill. Return to Bristol.

Postscript: From Theo Getty to Hugh Torrens (08/06/1969): "This excursion was quite a success, although the Bristol hotel was not exactly 5 Star. According to Mrs Donovan it's supposed to be the worst in Bristol, but nobody in the party seemed to grumble at it and it had the great advantage of being cheap!".

\section{North East Yorkshire, by John K. Wright}

Directors: L. Bairstow, J.E. Hemingway, M.K. Howarth, R.W. Knox, V. Wilson, J.K. Wright

Some 15 members of the party travelled by train on the morning of $17^{\text {th }}$ April to York, where they were met by Vernon Wilson and continued by coach to Scarborough. Here they stayed at the Delmont hotel on the North Side (and I stayed at my parent's house).

The programme for the excursion was as set out in the N.E. Yorks Guide. A problem for producing this was that what with Easter holidays, and a field trip to Ingleton after Easter, there was no time for me to get the revised manuscript of the guide to Hugh Torrens in time for him to print it. So when I got back, I was unable to go to either the London talks or the field trips from London, because I had to edit the manuscripts and put together with colleagues a "Chelsea edition" of the 45 page field guide. This includes Bairstow's lengthy contribution on the Lower Lias, which turned out to be his only publication on the Lower Lias of Robin Hoods Bay. This was referenced for many years by authors writing on the British Lower Jurassic until Howarth updated it in 2002. Copies of the guide were distributed to participants on the train going up to Yorkshire.

The drive from York to Scarborough enabled views and explanations of the scenery and the underlying geology, giving a good introduction to the area.

For the first field day on $18^{\text {th }}$ April I had produced a press release, which was faithfully reproduced in the Scarborough Evening News, largely about our visit to the Upper Jurassic at Hackness. For this, Vernon Wilson first took us to the exposure of the Hackness Coral-Sponge Bed and then, with muddy boots, we trooped into Hackess Hall. Here Lord Derwent proudly showed us the map of the geology of the Hackness Hills that William Smith had prepared when he was Land Steward there. We then went into Hackness Quarry, from which William Smith got his Hackness Building Stone. Ralph Imlay was keen to collect a Kosmoceras, but didn't find one, so I let him have one from my collection.

The second day, $19^{\text {th }}$ April, was a lengthy walk devoted mainly to the Upper Jurassic between Scarborough and Filey, starting in the Upper Deltaic Series then past White Nab to the south end of Cornelian Bay to see the Callovian and Oxfordian successions. We continued past Osgodby Nab and across Cayton Bay to the Red Cliff section of Callovian and Oxfordian, terminated by a fault, followed by Yons Nab and Gristhorpe Bay with plant beds (Gristhorpe Plant Bed) in the Middle Del- 
taic Series. From here the top of the cliff was followed to Filey Brigg and across the bay to catch a bus from Filey back to Scarborough.

Then during the four days ( $20^{\text {th }}$ to $24^{\text {th }}$ April) parts of the Middle and the whole of the lower Jurassic were examined in coastal exposures. This is the best and longest continuous exposure of Lias in Britain, and the most fossiliferous. When the tide was against us, inland excursions included a visit to the type locality of the Eller Beck Formation, where Bob Knox gave us the results of his recent $\mathrm{PhD}$ researches on this interesting formation, and a visit to Whitby Museum, where the Russian palaeontologists couldn't believe that there, in this small provincial museum, there were in the glass cases for all to see rows of ammonites which proved to be many of the holotypes of Martin Simpson and Stanley Buckman.

My memories also include following Leslie Bairstow across the rock platform in Robin Hoods Bay, and standing well back as he wielded his pick-axe to dig up Arnioceras and Asteroceras, and also showing the two Russian palaeobotanists the Scalby Ness section where they were able to collect Ginkgo. Their Russian colleague had come without a hammer, so I loaned him a large spare hammer from home which was normally used for breaking up lumps of coal, and he wielded this mightily on the Liassic concretions, saying "vairy good hammair" - his only English - as he did so.

\section{Western Scotland, by Nicol Morton}

\section{Directors: J.D. Hudson, N. Morton}

For this, the most adventurous excursion, there were 15 participants from 10 countries, plus two UK guides. Departure from London was on the evening of $16^{\text {th }}$ April, by overnight train to Inverness, continuing in the morning by train from Inverness to Kyle of Lochalsh. We continued by hired coach arriving northern Skye on 17th April. This coach was then with us for most of the excursions. We stayed two nights in the Staffin Hotel (dry, i.e., no alcohol!) for visits to the Middle and Upper Jurassic of northern Trotternish.

One of the day excursions here included the Upper Jurassic of Staffin Bay and the Great Estuarine Group at Duntulm. Bernard Ziegler and Andrzej Wierzbowski decided to stay with the Upper Jurassic in Staffin Bay for the whole day. The consequences of this are now, 53 years later, evident (the Kimmeridgian GSSP)! However, they missed, among many other things, seeing in the Great Estuarine Group at Duntulm a spectacular bedding surface with strange holes. These were identified many years later as dinosaur footprints (and the area has recently become internationally famous for dinosaur and other vertebrate fossils).

Other excursions concentrated on the unusual and very varied facies of the Bathonian Great Estuarine Group and visits to accessible sections in the Aalenian - Bajocian Bearreraig Sandstone Formation, with valuable ammonite finds, especially by Rene Mouterde and Gerd Westermann.

The party then moved to the Portree Hotel on the $19^{\text {th }}$ April, with two priorities - a glass of whisky for Rudi Trümpy (easy) and a catholic church for René Mouterde (not so easy in a strongly Protestant area; fortunately for me, although there was no priest, the Irish caretaker contacted by the hotel spoke French). From Portree there were excursions to Raasay, central Skye and Strathaird.

For Raasay we hired a fishing boat and hoped to land on the rocks at Rudha na Leac on the east coast as I had done with students four years earlier. Unfortunately, the waves were too large for this so we had to go back to the pier on the south-west corner of the island. Here we had to climb up a vertical ladder and then walk to the interesting sections in the centre and east side of the island. The Allt Fearns section in the Pabay Shale Formation (upper Sinemurian to Lower Pliensbachian) was one of the localities visited that yielded many fossils, including a find by Rene Mouterde of the first early liparoceratid specimen (later described by Donovan).

In central Skye the main interest was in the Broadford area with spectacular coastal flats in the fossiliferous Broadford Beds, the lower part (now the Breakish Formation) of Hettangian to lower Sinemurian age, includes two Hettangian coral beds. The upper part, of Sinemurian age (now the Ardnish Formation) shows plenty of Gryphaea beds and ammonites.

The Strathaird Peninsula has spectacular cliffs on both east and west coasts. On the east coast there are limited outcrops of Lower Jurassic but the main interest are the large-scale outcrops of Aalenian to Middle Bajocian tidal cross-bedded marine Bearreraig Sandstone Formation. On the west coast the section includes Bathonian lagoonal to deltaic brackish-water Great Estuarine Group and Callovian to Oxfordian marine sediments, partly thermally metamorphosed. Between the two there is a thin bed of marine black shales with the Upper Bajocian ammonite Garantiana.

The group photograph (Fig. 8) was taken by Milos Siblik at Armadale near the southernmost point on the Isle of Skye while we were waiting for the ferry to Mallaig for the return journey by train to London. For the Excursion directors this was 


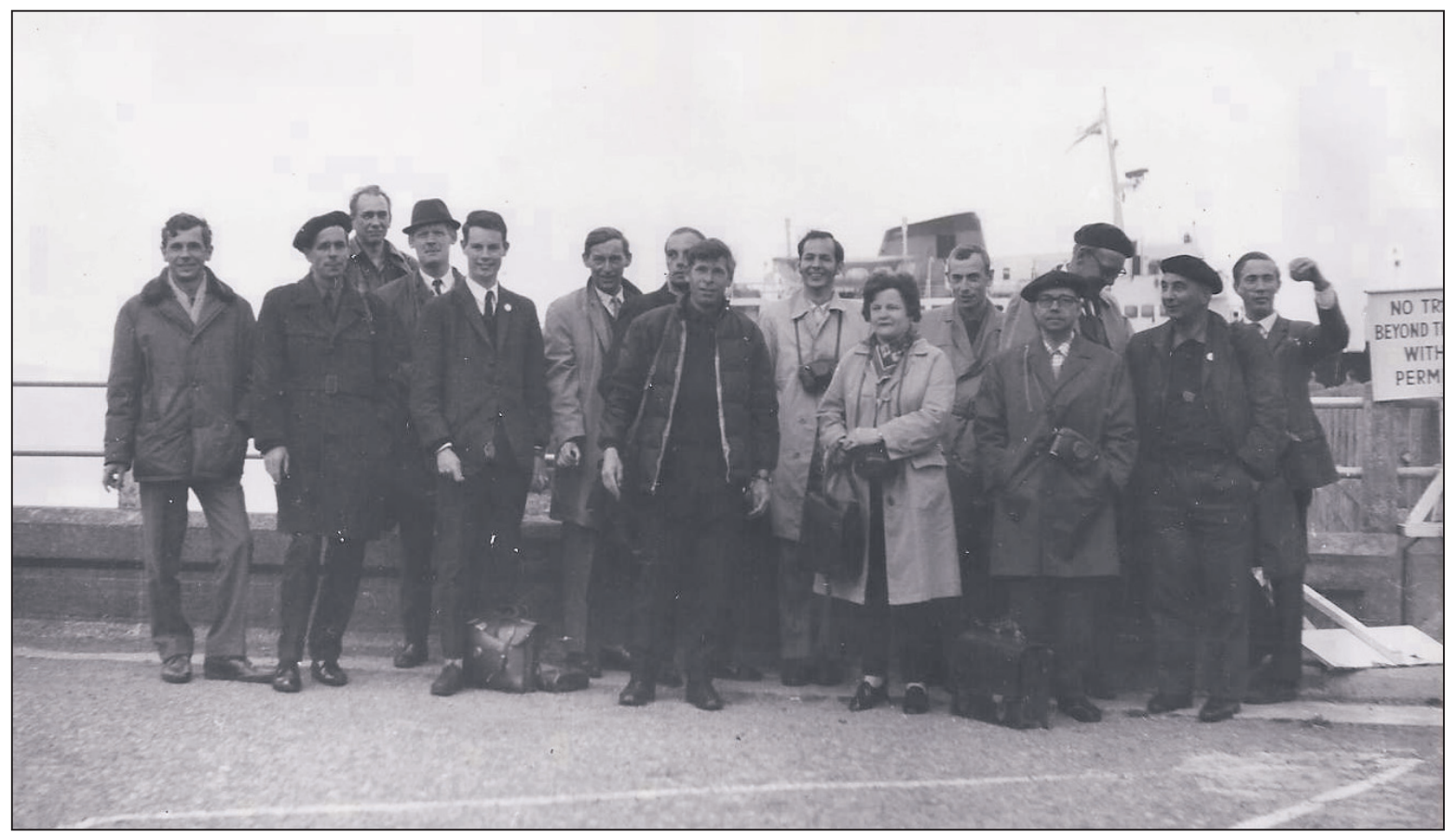

Fig. 8. The Western Scotland party waiting at Armadale in southernmost Skye for the ferry to Mallaig to join the train for the return to London, $23^{\text {rd }}$ April 1969.

From left to right - A. Wierzbowski, R. Dadlez, S. Nastaseanu, G.E.G. Westermann, N. Morton, J.H. Groiss, P. Biens, M. Goldberg, J. Ferrer, O. Nekvasilova, B. Ziegler, J. Bintz, R. Trümpy, R. Mouterde, J.D. Hudson. Photo by M. Siblik

our first visit to these outcrops with a group of experienced Jurassic specialists, with one result being that our fossil collections were improved as a result of presentations by participants of important new ammonite finds. It also led to future important Polish - British collaboration of long duration, culminating in the Staffin section being chosen as the base Kimmeridgian GSSP.

\section{Closing session}

$24^{\text {th }}$ April: Return to London for closing meeting and a reception given by British Petroleum at BP House, in the City of London, hosted by Peter E. Kent. On behalf of all the visitors Helmut Hölder expressed their thanks to those who had organized the Symposium. From D.V. Ager (1969): "Many compliments were paid both then and later to the high level of the organization, to the informal and friendly way in which the meeting had been arranged, and the many exciting new ideas that had flowered in this atmosphere".

\section{Postscript: September 1969 in Hungary, by Nicol Morton (with contributions by Hugh Torrens)}

The Symposium in Britain was followed in September of the same year by a Symposium on the Mediterranean Jurassic organized by our Hungarian colleagues. This was very important in further advancing progress in international co-operation and collaboration. The Symposium included presentation and discussions in Budapest and field excursions to the main Jurassic outcrops in Hungary, illustrating outcrops situations and a very different range of facies there from those that had been seen in Britain. At least nine British specialists presented papers (Fig. 9) and their participation in the field was significant, as Ager and Callomon solved the problem of dating the Villania stratigraphic horizon.

Personally I did not participate in the excursions because, in July to October of 1968, I (with my family) had been in Hungary for three months on a British Council/Hungarian exchange scheme. I had already visited the outcrops with my 
Hungarian colleagues (and I also knew who to invite to the William Smith Symposium). This is the third example mentioned in this report of the role in the 1960s of the British Council, in collaboration with partner institutions, in the promotion of international collaboration.

A historic review was published by Hugh S. Torrens "Some memories of Andras Galacz and of Hungary" in Hantkeniana, 9: 19-20, 2014.

\section{Return visit to Poland, September 1972, by Nicol Morton and Hugh S. Torrens}

In February 1972 four members of the Organising Committee of the 1969 William Smith Symposium in Britain, Derek V. Ager, John H. Callomon, Nicol Morton and Hugh $\mathrm{S}$. Torrens, were very pleasantly surprised to receive a letter from Prof. Roman Osika, Director of the Instytut Geologiczny of Poland:

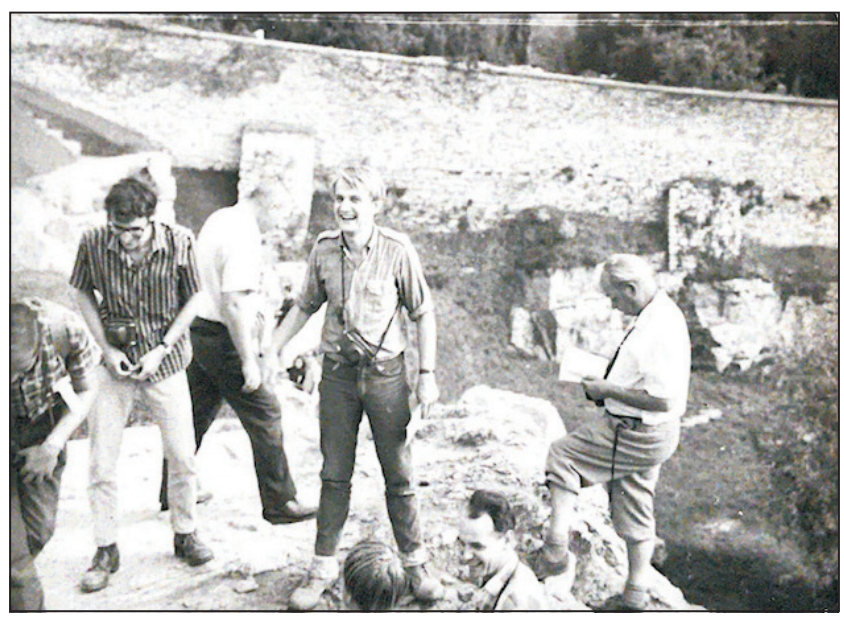

Fig. 9. The excursion to Villany on the 1969 Hungarian Geological Institute excursion.

From left to right - Hugh Jenkyns, Hugh Torrens and, below, Jobst Wendt

"In 1969 some geologists of my Institute had the opportunity to take part in the interesting International Field Symposium on the British Jurassic.

I appreciate the scientific cooperation with the British Jurassic specialists, and I really think it would be a fair contribution to the further development of this cooperation, if the British geologists had the occasion to get acquainted with the problems of the Polish Jurassic.

I hope that you are interested in these and therefor I invite you kindly to visit Poland for about 10 days in June or September 1972".

An outline programme for the 10 days in Poland was suggested, including discussions in the Geological Institute in Warsaw and in the University of Cracow and excursions to Jurassic sections.

"My Institute will care for all your expenses connected with accommodation, meals and transport in Poland".

All four of us were delighted to receive this recognition of the organization of our Symposium and honoured to accept this reciprocal invitation for a visit in September 1972, arriving on $6^{\text {th }}$ September and departing on $16^{\text {th }}$ September.

A second letter from Prof. Osaka on $18^{\text {th }}$ April gave details of our itinerary. Summarising:

Sept. $7^{\text {th }}$. Warsaw to Częstochowa; Upper Jurassic in Tomaszów Basin and Częstochowa area; overnight in Częstochowa [in the morning NM was very impressed by the many long queues outside the Cathedral before priests for confession, showing that the Catholic Church was very strong in Poland, and by the "Black Madonna" in the Cathedral].

Sept. $8^{\text {th }}$. Częstochowa to Cracow; Middle and Upper Jurassic of Cracow-Wieluń Ridge [HST recognized that we were passing Auschwitz and asked for us to visit. Three of us expressed our feelings that it was a very moving experience. HST noticed that JHC said nothing but many years later HST discovered why and also why he spoke German so well - he was born in Berlin but his family had escaped in 1937 to Britain because his mother was Jewish]; overnight in Cracow.

Sept. $9^{\text {th }}$. Around Cracow, Middle and Upper Jurassic of Cracow area, the spectacular outcrops of the Polish Jura; overnight in Cracow.

Sept. 10 ${ }^{\text {th }}$. Cracow to Zakopane; Upper Jurassic of Pieniny Klippen Belt; overnight in Zakopane [We discovered a ski resort there].

Sept. 11 ${ }^{\text {th }}$. Mesozoic of Polish Tatra Mountains; overnight in Zakopane.

Sept. 12 $^{\text {th }}$. Zakopane to Kielce; Lower, Middle and Upper Jurassic, south-western marginal zone of the Holy Cross Mountains; overnight in Kielce.

Sept. 13 $^{\text {th }}$. Kielce to Warsaw; Rhaetic, Middle and Upper Jurassic of the southern margin of the Holy Cross Mountains; overnight in Warsaw.

Sept. $\mathbf{1 4}^{\text {th }}-\mathbf{1 5}^{\text {th }}$. Visits to the Geological Instutute, the Polish Academy of Sciences and the University of Warsaw. We all greatly appreciated the opportunity of discussions with our Polish colleagues; for JHC especially to meet with his sexual dimorphism in ammonites "rival" Henryk Makowski; overnights in Warsaw. 
Not only were all expenses paid by the Geological Institute but we were each given money we could not spend because it was not necessary. NM remembers buying in Warsaw a wooden chess set for the family!

This visit to Poland was a fantastic experience for all of us and certainly for broadening our experience. The consequences of developing such international collaboration and friendship have continued on both sides until now. We cite two examples: 1. In September 2002 the $5^{\text {th }}$ International Symposium of the Jurassic Subcommission was held in Palermo, Sicily and a public vote selected Poland to host the $6^{\text {th }}$ ISJS Symposium in 2006. This was based in Cracow and we visited again some geological sites the four of us had seen in 1972.

2. The second is the long period of international collaboration, especially Polish-British, on investigations of options for the GSSP of the Kimmeridgian Stage. The recent positive result of this project has its roots in the 1969 William Smith Symposium in Britain, in particular the excursion to Western Scotland.

Editor's note. Over 50 years have passed since the William Smith Bicentenary Symposium took place in London with long field excursions to key areas. The Symposium, as well as the earlier Luxembourg Symposia, opened a new phase in international co-operation between scientists of many countries in Jurassic geology, drastically broken by the Second World War. This was heavily pronounced, especially in Europe - where the western and eastern parts of the continent were strictly isolated by the "iron curtain" as a consequence of the disaster of war. The William Smith Bicentenary Symposium in April 1969 brought together for the first time, in a unique way, so many (about 200) geologists from 24 countries working on the Jurassic System. It resulted in the appearance of new ideas, direct contacts for scientific collaboration and simply friendship. The editors of Volumina Jurassica are very grateful to Nicol Morton, John Cope, Hugh Torrens and John Wright for preparation of their personal reminiscences as a reminder in a special way this remarkable Symposium. 